\title{
Factors affecting diatom dynamics in the alpine lakes of Colbricon (Northern Italy): a 10-year survey
}

\author{
Renata TREVISAN*, Claudia POGGI and Andrea SQUARTINI ${ }^{1)}$ \\ Dipartimento di Biologia, Università di Padova, Viale G. Colombo 3, 35129 Padova, Italy \\ ${ }^{1)}$ Dipartimento di Biotecnologie Agrarie, Università di Padova, Viale dell'Università 16, 35020 Legnaro, Padova, Italy \\ *e-mail corresponding author: renata.trevisan@unipd.it
}

\begin{abstract}
Planktonic diatom fluctuations, their diversity and relationships with environmental variables were analyzed for ten consecutive years in Colbricon Superiore and Inferiore, two small high-mountain lakes located in the Paneveggio-Pale di S. Martino Natural Park (Trento, Italy) offering the rare opportunity to study two lakes differing only by area and volume and being in this respect in a ratio of 2:1 and 3:1 respectively. The lakes were monitored and sampled monthly, during ten ice-free periods, from 1998 to 2007, to correlate water chemical and physical characteristics with the recorded diversity and abundance of planktonic diatoms. 55 taxa of Bacillariophyceae were found, among which Cyclotella spp., Tabellaria flocculosa and Fragilaria spp. were dominant. Both chemical data and diatom community composition are consistent with well buffered mesotrophic lakes. We found statistical evidence that the development of diatoms was strongly related to the variation of water temperature. Furthermore, several different signatures of the diatom-enviroment relationships arose between the two lakes as e.g., a negative correlation between diatom development and water transparency was occurring in the larger lake only. As a result, the average diatom density recorded over the 10 years period were 1.17 fold higher than in the lower lake which corresponds to a 1.65 fold higher biomass. A size-dependent tighter response of the phytoplankton to chemical parameters appears to operate in the smaller waterbody compared to the larger one.
\end{abstract}

Key words: high-mountain lakes, diatoms, environmental variables, Paneveggio-Pale di S. Martino Natural Park

\section{INTRODUCTION}

High mountain lakes constitute prime habitats for ecological studies (Lami \& Boggero 2006). In general they are regarded as "small, fragile, highly individual ecosystems, like islands of biodiversity surrounded by a sea of land" (ARPAV 2007). In Italy the most of small natural lakes, smaller than $0.2 \mathrm{~km}^{2}$, are present on the Alps and prevalently they are brought about by the glacial modelling, determining the formation either of basin erosion or of morenic barrier. The most frequent ones are "cirque lakes" which are often placed in groups and in altimetric sequence (Barbanti et al. 1993); the highest lakes are more recent than the lowest ones and they are fed by snow melting and rainfall, their depth is relatively low and the water level is often fluctuating. (Mosello et al. 2000).

Remote mountain lakes are exposed to harsh climatic conditions, including low temperatures, short ice-free periods, variations in precipitation (snow), which may cause pronounced seasonal variations in water chemistry (Nauwerck 1994; Koinig et al. 1998) and changes in biotic assemblages (Fott et al. 1999; Hinder et al. 1999). These ecosystems generally do not show evident antropic disturbances, such as singlepoint pollution sources or changes of land use in the drainage area. Due to the geological characteristics of the catchment areas in the mountain region, as is the case of the acid bedrock Lagorai range, many high mountain lakes are poorly buffered and several of them display acidification phenomena (Boggero et al. 1998). For all these reasons they are considered simple and labile ecosystems able to react readily to environmental changes and stresses. Thanks to their sensitivity high mountain lakes can function as early warning systems (Nauwerck 1994). Mountain lakes have been regarded as particularly suitable indicators for environmental changes related to climate and other factors (Schmidt et al. 2004). Analyses of the biotic components and their fluctuations can in this sense provide insights on ongoing dynamics and facilitate their predictions for either management or conservation purposes. The analyses of patterns occurring in mountain lakes can allow to extrapolate models for the interpretation of global ecological phenomena.

The notions on algal communities of high mountain lakes concur to indicate that rather than endemic or specialized taxa, these environments display a rarefaction on the general checklist found in larger lakes at lower altitudes (Nauwerck 1966; Catalan et al. 2009). Moreover, the process of selection of the species able to persist in these alpine environments is determined by the capability of surviving the alternating phases of short vegetative periods and ice-covered stages, with adaptation to opposite light regimes, from the intense summer radiation to the weak ice-filtered shady winter situation. Phytoplankton species in these contexts need also to endure low nutrient availability and fluctuating 
water regimes due to atmospheric precipitations and freezing/thawing cycles (Salmaso \& Decet 1997) Adaptation traits include small dimension (Tilzer 1972) and active movement capabilities through flagella (Pechlaner 1971; Reynolds et al. 2002).

In general low phytoplankton biovolumes are observed in these lakes with the possibility of seasonal peaks in summer or fall (Nauwerck 1966; Rott 1988; Kernan et al. 2009) High values can be due also to nutrient increase or interactions with other members of the community. Studies have been also dedicated to the analysis of effects of global climate change on these communities. (Cabrera et al. 1997; Halac et al. 1997; Curtis et al. 2009). In classic studies the presence of diatoms as well as that of cyanobacteria was considered a minor component of high mountain lakes communities (Nauwerk 1966; Pechlaner 1971; Pfister 1988). More recent reports indicate how groups as diatoms can instead be a major contributor to the phytoplankton biomass (ARPAV 2007; Vanormelingen et al. 2008).

Diatoms are considered as one of the most successful examples of photosynthetic eukaryotic members of the phytoplankyon. They are encountered in almost any kind of water environment, and are known also as endosymbionts in dinoflagellates and foraminifers (Round et al. 1990). Their contribution to the biogeochemical cycles is significant, providing $20-25 \%$ of the globally fixed carbon (Mann 1999). Diatoms biology has been the object of many studies exploiting their role as prime bioindicators for quality of water body, climate change as well as useful tools for paleolimnology (Round et al. 1990; Ampel et al. 2008; Payette 2008; Vanormelingen 2008; Curtis et al. 2009). Several aspects of their taxonomy and ecology however still warrant deeper investigations (Mann 1999; Chepurnov et al. 2004) and long-term surveys can offer in this respect useful insights.

The known relationships between diatoms and environmental factors have been reviewed; this algal group is reported to be a good competitor in turbulent water conditions or at the onset of stratification in low light, low temperature and nutrient conditions not overly oligotrophic. Their photosystem is rapidly damaged when exposed to intense light (Willen 1991; Reynolds et al. 2002).

Studies performed by modeling nutritional parameters showed that $\mathrm{P}$, instead of $\mathrm{Si}$, was the element that mostly limited the development of diatom biovolume. In any event, the rate at which phosphorus was supplied was not responsible for the differences among years. The causes of success of different spring diatoms populations were ascribed to differences in the system hydrology, as deduced from model simulations involving sinking, washout rates and Si uptake (Ferris \& Lehman 2007). Extensive ecological studies on diatoms in high mountain lakes have been carried out pointing out a number of common trends and shaping factors (Tolotti 2001; Catalan et al. 2009; Kernan et al. 2009).

In the present study we aimed at analyzing, over an extended period of time, the phytoplankton dynamics in two high mountain lakes to put in evidence the possible correlations with climatic and chemical variables in shaping the diatoms communities. A further objective was to compare the situation of the upper Lake Colbricon Superiore with that of the lower Lake Colbricon Inferiore. For such purpose we took advantage of the rare opportunity offered by the two lakes under analysis. Lying one next to the other, they feature a volumetric configuration in which the smaller lake has a volume of one third with respect to the one of the larger lake, allowing a unique set up to investigate sizerelated effects in waterbodies within the same landscape.

\section{METHODS}

\subsection{The site}

We analyzed Lake Colbricon Superiore (1922 m a.s.1.) and Lake Colbricon Inferiore (1910 m a.s.1.), hereafter referred to as LCS and LCI, respectively, which are two alpine lakes located in the Lagorai mountain range, within the Avisio basin, in the Paneveggio-Pale di S.Martino Natural Park (Trento, Italy). (Map in Fig. 1). These two water bodies differ by size being the superior about three times the volume of the inferior one and twice its surface. LCS (max depth $12 \mathrm{~m}$, average depth $5.4 \mathrm{~m}$ ) features a surface nearly double than the one of LCI (max depth $8 \mathrm{~m}$, average depth $3.8 \mathrm{~m}$ ) and a volume about three times larger. The area of LCS is $0.024 \mathrm{~km}^{2}$ and its volume is $0.13 \mathrm{~km}^{3}$, while the values for LCI are $0.013 \mathrm{~km}^{2}$ and $0.05 \mathrm{~km}^{3}$, respectively. Their close proximity (less than 50 meters apart from each other) and the consequent sharing of the same water catchment basin, constitutes a rare set of features allowing important size-dependent comparisons. The lakes lie on peat soil, over a bedrock substratum of quartziferous porphyry, and are surrounded by a sphagnum and sedge vegetation (Festi \& Prosser 2000). As glacial cirque lakes they are small and relatively shallow, with a maximum depth respectively of $12 \mathrm{~m}$ and $8 \mathrm{~m}$; they are dimictic, undergoing complete mixing in spring and autumn, and their morphological and hydrological features have been previously described (Trevisan \& Rosso 2001). In this study we analyzed the diatom community in the two Colbricon lakes, during ten consecutive years.

\subsection{Field methods and laboratory analyses}

The analysis schedule involved on average 7 sampling dates each year yielding in total 69 samplings per lake. Both lakes were monitored and sampled during ten years, about monthly. As these lakes generally 

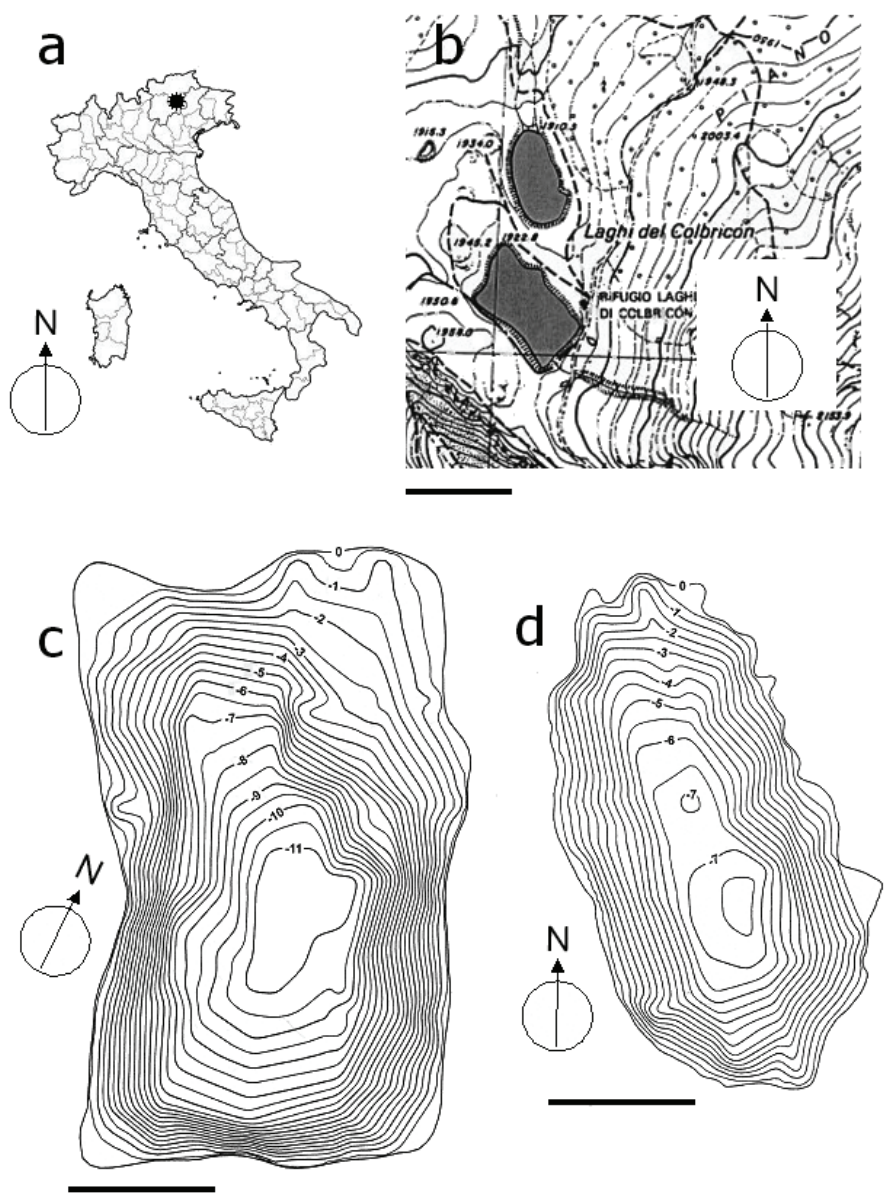

Fig. 1. a) Indication of the site location in Italy; b) local map of the area; c, d) batimetric maps of the LCS (c) and LCI (d). Scale bars represent $200 \mathrm{~m}$ in $\mathrm{b}$ and $50 \mathrm{~m}$ in $\mathbf{c}$ and $\mathbf{d}$.

freeze from November to May, the sampling scheme equals to the ten ice-free periods between years 1998 and 2007. Hydrometric level, air and water temperature, transparency, $\mathrm{pH}$ and conductivity were measured on the spot, while chemical analysis of water samples (depth-integrated across the water column) were performed at the Institute for the Study of Ecosystems CNR-ISE of Verbania-Pallanza according to standard methods (Tartari \& Mosello 1997). Trophic classification of the lakes was defined using indexes based on Secchi disk transparency and total phosphorus concentration, according to Hakanson (1980) and to the O.E.C.D. model (O.E.C.D. 1982). Chemical and physical parameters were compared with biomass and density of the bacillariophyceae assemblages. Water samples for taxonomic analysis of diatoms were collected with a $25 \mu \mathrm{m}$ plankton net, while integrated samples from the whole water column for analysis of diatom density and biomass were sampled by a plastic flexible siphon tube. Samples were fixed with Lugol's solution and were observed with optical and inverted microscope at $400 \times$ magnification, in accordance with the Utermohl technique (Utermohl 1958), and with the help of SEM for some specific identifications. The textbooks of Krammer \& Lange-Bertalot (1986, 1991, 1998) were used for taxonomic determination of diatoms. Sample biomass was estimated by multiplying known reference biovolumes for the different taxa identified. For the ecological evaluation of the habitat quality based on the taxa found and their abundances we applied the Indice Biologique Diatomée (IBD) analysis (Prygiel \& Coste 1998). Relative Water Column Stability (RWCS) was calculated as described by Padisak et al. (2003).

With the aim of studying possible correlations between diatom fluctuations and environmental parameters variation, regression analysis was performed, using CoStat (CoHort Software, Monterey CA, USA) and SPSS $^{\circledR}$ software (SPSS Inc., Chicago, IL, USA).

\section{RESULTS}

The mean water temperatures for the whole period resulted $11.17^{\circ} \mathrm{C}$ for LCS and $11.35{ }^{\circ} \mathrm{C}$ for LCI. The Relative Water Column Stratification Stability, RWCS (Padisak et al. 2003) values showed, over the ten years period, an average value of 50.34 for LCS and 36.55 for LCI. 
Tab. 1. Ranges of the main physical and chemical water parameters of Colbricon lakes during the ten years of study, from 1998 to 2007 . * The water level measurement is relative to a graduated stick set at $100=1922 \mathrm{~m}$ a.s.l. (LCS) and $100=1910 \mathrm{~m}$ a.s.l. (LCI).

\begin{tabular}{|c|c|c|c|c|c|c|}
\hline & \multicolumn{3}{|c|}{ L. Colbricon Superiore } & \multicolumn{3}{|c|}{ L. Colbricon Inferiore } \\
\hline & mean & $\min$ & $\max$ & mean & $\min$ & $\max$ \\
\hline Mean water $\left(\mathrm{T}^{\circ} \mathrm{C}\right)$ & 11.2 & 2.0 & 18.0 & 11.3 & 2.0 & 18.0 \\
\hline Water level $\left(\mathrm{cm}^{*}\right)$ & 101 & 92 & 115 & 90 & 76 & 111 \\
\hline Transparency (m) & 5.0 & 1.1 & 8.4 & 4.15 & 1.2 & 7.0 \\
\hline $\mathrm{pH}$ & 7.3 & 6.9 & 7.6 & 7.4 & 6.9 & 8.2 \\
\hline$\left.\chi 20^{\circ} \mathrm{C}(\mu \mathrm{S} \mathrm{cm})^{-1}\right)$ & 45.8 & 40.0 & 49.9 & 44.2 & 37.6 & 55.0 \\
\hline T.Alc. $\left(\right.$ meq L L $\left.{ }^{-1}\right)$ & 0.44 & 0.37 & 0.49 & 0.44 & 0.34 & 0.67 \\
\hline $\mathrm{Cl}\left(\mathrm{mg} \mathrm{L}^{-1}\right)$ & 0.41 & 0.28 & 0.75 & 0.40 & 0.27 & 0.71 \\
\hline $\mathrm{SO}_{4}\left(\mathrm{mg} \mathrm{L}^{-1}\right)$ & 1.64 & 1.37 & 1.62 & 1.53 & 1.13 & 1.99 \\
\hline $\mathrm{Ca}\left(\mathrm{mg} \mathrm{L}^{-1}\right)$ & 8.53 & 7.15 & 9.86 & 8.49 & 6.30 & 12.70 \\
\hline $\operatorname{Mg}\left(\mathrm{mg} \mathrm{L}^{-1}\right)$ & 0.31 & 0.27 & 0.33 & 0.28 & 0.22 & 0.46 \\
\hline $\mathrm{Na}\left(\mathrm{mg} \mathrm{L}^{-1}\right)$ & 0.80 & 0.70 & 0.95 & 0.84 & 0.71 & 1.04 \\
\hline $\mathrm{K}\left(\mathrm{mg} \mathrm{L}^{-1}\right)$ & 0.32 & 0.11 & 0.50 & 0.23 & 0.16 & 0.58 \\
\hline $\mathrm{N}-\mathrm{NO}_{3}\left(\mu \mathrm{g} \mathrm{L}^{-1}\right)$ & 135 & 44 & 204 & 149 & 5 & 268 \\
\hline $\mathrm{N}-\mathrm{NH}_{4}\left(\mu \mathrm{g} \mathrm{L}^{-1}\right)$ & 83 & 28 & 140 & 68 & 12 & 213 \\
\hline $\mathrm{TN}\left(\mu \mathrm{g} \mathrm{L}^{-1}\right)$ & 440 & 310 & 630 & 470 & 280 & 870 \\
\hline $\mathrm{RP}\left(\mu \mathrm{g} \mathrm{L}^{-1}\right)$ & 2 & 1 & 5 & 5 & 2 & 18 \\
\hline $\mathrm{TP}\left(\mu \mathrm{g} \mathrm{L}^{-1}\right)$ & 12 & 4 & 37 & 14 & 3 & 47 \\
\hline $\mathrm{Si}\left(\mathrm{mg} \mathrm{L}^{-1}\right)$ & 0.94 & 0.60 & 1.42 & 1.32 & 0.91 & 1.79 \\
\hline
\end{tabular}

The minimum and maximum values were in both lakes $2{ }^{\circ} \mathrm{C}$ and $18{ }^{\circ} \mathrm{C}$, respectively. As regards the chemical data, these are summarized in table 1 . In both lakes the average $\mathrm{pH}$ values were close to neutrality (7.3-7.4) and the mean conductivity was low, with values around $45 \mu \mathrm{S} \mathrm{cm}^{-1}$ consistent with a limited salinity condition. The mean concentrations of total nitrogen (TN) were $440 \mu \mathrm{g} \mathrm{L}^{-1}$ in LCS and $470 \mu \mathrm{g} \mathrm{L}^{-1}$ in LCI, while those of total phosphorus (TP) were $12 \mu \mathrm{g} \mathrm{L}^{-1}$ in LCS and $13.7 \mu \mathrm{g} \mathrm{L}^{-1}$ in LCI. The latter qualifies as the limiting growth factor for phytoplankton, as indicated by the TN/TP ratio, that always resulted over 10 (Chiaudani \& Vighi 1974). The concentration of reactive phosphorus was the only parameter for which the lower and smaller lake showed a remarkable difference from the upper one. The amounts recorded were 2.43 $\mu \mathrm{g} \mathrm{L}^{-1}$ (LCS) vs $4.71 \mu \mathrm{g} \mathrm{L}^{-1}$ (LCI). Mean silica concentrations were also higher in the lower lake, amounting $0.94 \mathrm{mg} \mathrm{L}^{-1}$ in LCS and 1.32 in LCI. During the period observed both lakes comply to the definition of mesotrophic, showing mean transparency values respectively of 5 and $4.15 \mathrm{~m}$, and total phosphorus concentrations during the spring mixing periods of 12 and $19 \mathrm{mg} \mathrm{m}^{-3}$ (Hakanson 1980; O.E.C.D. 1982). The microscopy observations of the 138 integrated samples collected in Colbricon lakes. during the ten years of study, allowed identification of phytoplankton species including 55 taxa of Bacillariophyceae resulting from the quantitative analysis (Tab. 2), while when using the plankton net the full qualitative analysis extended the count to 78 species. Some taxa were found to be recurring and numerically dominant. In some sampling dates their numbers reached values above 1000 cells $\mathrm{mL}^{-1}$, while in other times none of the bacillariophyceae exceeded the 5-10 units per $\mathrm{mL}^{-1}$. Among the dominant species, Cyclotella spp. and Tabellaria flocculosa resulted prevalent mostly in spring and in autumn, or in correspondence of low algal biomass periods. Different species of Fragilaria (i.e. F. crotonensis, F. capucina, $F$. ulna and $F$. tenera) often showed preponderant abundance values in summer, and were responsible of diatom growth peaks. The mean annual density of the diatoms amounted to: 233.7 cells $\mathrm{mL}^{-1}$ in LCS vs 273.5 cells $\mathrm{mL}^{-1}$ in LCI. The corresponding mean annual biovolumes (estimated by multiplying for the unit volume of each taxon) resulted $146.2 \mathrm{~mm}^{3} \mathrm{~m}^{-3}$ in LCS and $242.6 \mathrm{~mm}^{3} \mathrm{~m}^{-3}$ in LCI.

In order to have an assessment in ecological terms we applied the Indice Biologique des Diatomees (IBD) analysis. Such index was devised as an indicator of water quality on the basis of the diatom communities assemblages. Originally designed for rivers it has later been applied to lakes as well. It can span between a minimum of 1 (very bad water quality) and a maximum of 20 (very good water quality). The IBD value for the 10-years average of LCS was 14.5 while for LCI we found an IBD of 15.4 The ecological quality of both lakes is ranked as 'good' as it falls in the fourth level (between 13 and 17) in a scale of five as judged by the results of the IBD with the LCI appearing slightly better. The IBD involves the definition of probability profiles for each of the taxa across seven quality classes. The two high mountain lakes result only moderately affected by pollution although not immune. The lower index of the upper lake could be consistent with the presence of a shelter for visitors with cooking and bathroom facilities on the shore and with a consequently higher number of hikers compared with the lower lake.

As regards correlations between chemical or physical parameters and biological counts, the linear regression analysis highlighted a number of significant instances. As table 3 summarizes, the diatoms density 
Tab. 2. List of the diatom taxa observed in the two lakes and their mean density and biomass throughout the 10 years. The presences column indicate in how many of the 69 samplings a given taxon was found. Out of 55 taxa encountered only those having a mean density $>0.98$ in at least one of the two lakes are shown. The 10 -years average density of the diatoms was 146.2 for LCS and 242.6 cells $\mathrm{mL}^{-1}$ for LCI while the corresponding biovolume (estimated by multiplying for the unit volume of each taxon) was $233.7 \mathrm{in} \mathrm{LCS} \mathrm{and} 273.5 \mathrm{~mm}^{3} \mathrm{~m}^{-3}$ in LCI.

\begin{tabular}{|c|c|c|c|c|c|c|}
\hline \multirow[b]{2}{*}{ Taxon } & \multicolumn{3}{|c|}{ L. Colbricon Superiore } & \multicolumn{3}{|c|}{ L. Colbricon Inferiore } \\
\hline & $\begin{array}{l}\text { mean density } \\
\left(\text { cells } \mathrm{mL}^{-1}\right)\end{array}$ & presences & $\begin{array}{l}\text { mean biomass } \\
\left(\mathrm{mg} \mathrm{m}^{-3}\right)\end{array}$ & $\begin{array}{l}\text { mean density } \\
\left(\text { cells } \mathrm{mL}^{-1}\right)\end{array}$ & presences & $\begin{array}{c}\text { mean biomass } \\
\left(\mathrm{mg} \mathrm{m}^{-3}\right)\end{array}$ \\
\hline Achnantes minutissima & 7.7 & 49 & 0.78 & 9.46 & 44 & 0.96 \\
\hline Achnantes spp. & 1.26 & 13 & 0.32 & 1.92 & 17 & 0.49 \\
\hline Caloneis silicula & 0.05 & 1 & $<0.01$ & 1.01 & 9 & 3.4 \\
\hline Cocconeis placentula & 1.14 & 11 & 1.71 & 0.71 & 23 & 1.05 \\
\hline Cocconeis sp. & 1.56 & 17 & 0.95 & 0.56 & 20 & 0.34 \\
\hline Cyclotella comensis & 1.94 & 6 & 0.3 & 37.14 & 52 & 5.65 \\
\hline Cyclotella spp. & 47.84 & 46 & 12.13 & 0.79 & 5 & 0.2 \\
\hline Cymbella helvetica & 2.09 & 23 & 8.86 & 2.29 & 38 & 9.71 \\
\hline Cymbella silesiaca & 0.02 & 1 & $<0.01$ & 2.9 & 37 & 3.51 \\
\hline Cymbella spp. & 1.96 & 33 & 5.07 & 1.83 & 12 & 4.74 \\
\hline Diatoma hyemalis & 1.13 & 11 & 0.91 & 1.61 & 14 & 1.29 \\
\hline Diatoma mesodon & 0.06 & 4 & 0.01 & 3.82 & 20 & 0.47 \\
\hline Diatoma spp. & 3.62 & 25 & 1.1 & 2.55 & 24 & 0.78 \\
\hline Diploneis ovalis & 0.52 & 4 & 0.28 & 1.24 & 14 & 0.69 \\
\hline Eunotia bilunaris & 0.82 & 20 & 0.21 & 2.53 & 22 & 0.64 \\
\hline Fragilaria capucina & 7.42 & 28 & 7.52 & 41.79 & 43 & 42.38 \\
\hline Fragilaria crotonensis & 81.36 & 37 & 24.76 & 66.95 & 42 & 20.37 \\
\hline Fragilaria pinnata & 1.66 & 21 & 0.67 & 0.01 & 1 & $<0.01$ \\
\hline Fragilaria sp. & 0.87 & 10 & 0.35 & 1.05 & 12 & 0.42 \\
\hline Fragilaria tenera/ulna & 26.59 & 46 & 8.09 & 23.94 & 43 & 7.28 \\
\hline Gomphonema spp. & 0.55 & 16 & 1.18 & 1.06 & 19 & 2.34 \\
\hline Gomphonema truncatum & 0.68 & 10 & 1.99 & 1.09 & 12 & 3.3 \\
\hline Melosira spp. & 3.9 & 11 & 1.19 & 1.66 & 9 & 0.5 \\
\hline Navicula cryptocephala & 2.7 & 24 & 3.81 & 6.68 & 33 & 9.46 \\
\hline Navicula lanceolata & 1.18 & 15 & 1.64 & 0.02 & 1 & $<0.01$ \\
\hline Navicula pupula & 0.24 & 7 & 0.23 & 2.7 & 18 & 2.73 \\
\hline Navicula radiosa & 1.66 & 25 & 5.72 & 3.48 & 31 & 12.16 \\
\hline Navicula spp. & 4.85 & 46 & 18.48 & 8.54 & 40 & 32.72 \\
\hline Nitzschia spp. & 2.34 & 18 & 2.12 & 0.55 & 13 & 0.49 \\
\hline Pinnularia major & 0.43 & 1 & $<0.01$ & 1.32 & 15 & 27.11 \\
\hline Pinnularia spp. & 1.44 & 20 & 2.15 & 0.81 & 14 & 1.2 \\
\hline Pinnularia sudetica & 0.07 & 1 & $<0.01$ & 4.18 & 29 & 20.86 \\
\hline Stauroneis anceps & $<0.01$ & 1 & $<0.01$ & 2.22 & 22 & 0.67 \\
\hline Stauroneis spp. & 3.12 & 39 & 1.26 & 2.88 & 33 & 1.16 \\
\hline Tabellaria flocculosa & 12.53 & 46 & 3.18 & 20.79 & 38 & 5.27 \\
\hline Tabellaria spp. & $<0.01$ & 1 & $<0.01$ & 2.27 & 9 & 0.35 \\
\hline
\end{tabular}

Tab. 3. Results of the correlation analysis between diatom density or biomass in the two lakes and the different independent variables examined. Only the ones which resulted in significant correlations are shown. The Pearson product moment correlation coefficient $\mathrm{r}$ is reported along with the probability $\mathrm{P}$ that its value could be $=0$.

\begin{tabular}{lllllll}
\hline & surface water T. & mean water T. & RWCS & Conductivity & Transparency & Water level \\
\hline CS Density & $r: 0.25 P: 0.037^{*}$ & $r: 0.33 P: 0.010^{*}$ & $r: 0.310 P: 0.021^{*}$ & $r:-0.17 P: 0.163$ & $r:-0.51 P: 0.000^{* * *}$ & $r: 0.003 P: 0.977$ \\
CS Biomass & $r: 0.25 P: 0.035^{*}$ & $r: 0.35 P: 0.007^{* *}$ & $r: 0.219 P: 0.106$ & $r:-0.28 P: 0.019^{*}$ & $r:-0.47 P: 0.0001^{* * *}$ & $r:-0.04 P: 0.724$ \\
CI Density & $r: 0.29 P: 0.016^{*}$ & $r: 0.31 P: 0.018^{*}$ & $r: 0.351 P: 0.0099 * *$ & $r: 0.12 P: 0.295$ & $r:-0.15 P: 0.211$ & $r:-0.26 P: 0.031^{*}$ \\
CI Biomass & $r: 0.28 P: 0.019^{*}$ & $r: 0.32 P: 0.015^{*}$ & $r: 0.246 P: 0.0754$ & $r: 0.09 P: 0.436$ & $r:-0.23 P: 0.054$ & $r:-0.16 P: 0.183$ \\
\hline
\end{tabular}

and biomass had a statistically significant positive correlation $(p<0.05)$ with water temperature, either measured at surface or in the water column average. Such relationship can be also followed by looking at the correspondence of diatom peaks with temperature rises in figure 2. A strong negative correlation $(p<0.0001)$ with water transparency resulted in LCS for both density and biomass, while in LCI the correlation was not significant. The lower lake had also a negative signifi- cant correlation with diatom density and water level, which was not displayed by the upper lake. A correlation between RWCS and diatom densities was observed whose significance resulted higher in LCI. In several instances, the link between temperature and diatom proliferation can be observed also in figure 2 by the consistent match of abundance peaks and warmer waters either preceding the bloom or in a more simultaneous fashion. 

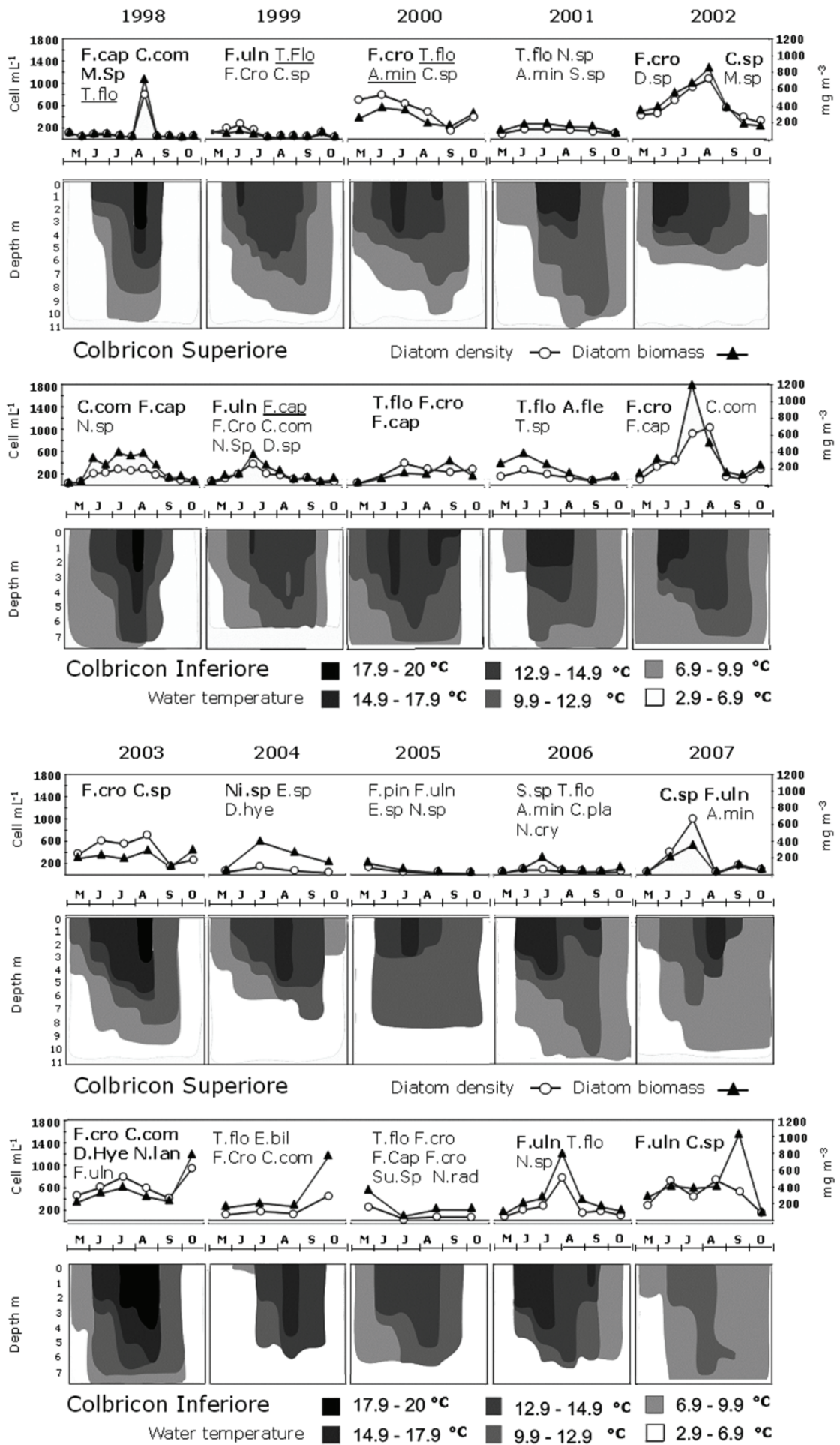

Fig. 2. Densities and biomass volumes of diatoms during the ten ice-free periods 1998-2007 and corresponding water column temperatures. Abundant taxa observed in the different years are indicated. A.min: Achnantes minutissima, C.com: Cyclotella comensis, C.sp: Cyclotella sp., D.hye: Diatoma hyemalis, D.sp: Diatoma sp.,. E.bil: Eunotia bilunata, E.sp: Eunotia sp., F.cap: Fragilaria capucina, F.cro: Fragilaria crotonensis, F.pin: Fragilaria pinnata, F.uln: Fragilaria ulna, M.sp: Melosira sp., N.sp: Navicula sp., Ni. Sp: Nitzschia sp., N.cry: Navicula cryptocephala, N.lan: Navicula lanceolata, N.rad:, Navicula radiosa, S.sp: Stauroneis sp., Su.sp: Surirella sp.,T.flo: Tabellaria flocculosa, T.fen: Tabellaria fenestrata, C.pla: Cocconeis placentula, A. fle: Achnantes flexella. Boldface: $>100$ cells $\mathrm{mL}^{-1}$ (in at least one sampling date), Underlined: $>50<100$ cells $\mathrm{mL}^{-1}$, Plain text: $>10<50$ cells/ml (within this category only the most frequently recurring cases are listed). 

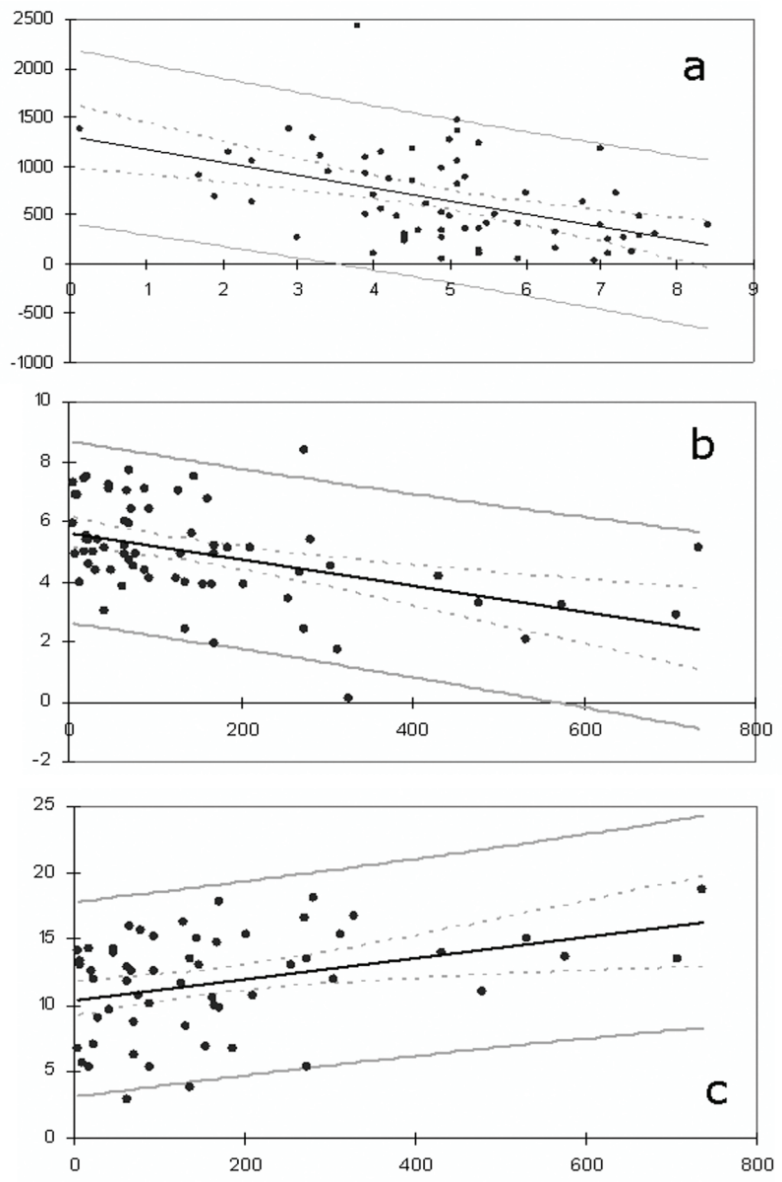

Fig. 3. Linear regression plots of the main combinations of variables resulting in significant correlations with $P$ values $<0.001$ (Tab. 3). a) Water transparency (X) by diatom density (Y) in LCS; b) Water transparency (X) by diatom biomass (Y) in LCS; c) Water temperature $(\mathrm{X})$ by diatom biomass $(\mathrm{Y})$ in LCS. Fitted models and regression lines are shown with $95 \%$ confidence intervals (observations confidence intervals: thin solid lines; mean confidence intervals: broken lines).

The regression plots of the main variables resulting in significant correlations can be observed in figure 3 .

Concerning more loosely associated variables conductivity is negatively correlated with diatoms biomass only in the larger LCS. Other variables, as previous week rainfall, $\mathrm{pH}$, and air temperature did not yield significant correlations with diatom density nor biomass in any of the lakes.

\section{DISCUSSION}

The chemical values displayed by the two lakes show common features, consistent with the fact that they belong to the same hydrological basin and are connected by a short effluent from LCS. Being the substrates non-alkaline quartziferous rocks, not conducive to buffering dissolved carbonates, the observed $\mathrm{pH}$ values can be considered to indicate the absence of acid rain phenomena (Trevisan \& Rosso 2001). Nitrogen and phosphorus concentrations agree with the trophic classification (Hakanson 1980; O.E.C.D. 1982), while rather low silica concentrations were present, as expected for high mountain conditions, where low temperature limits $\mathrm{SiO}_{2}$ dissolution rates and substan- tial precipitation as rain or snow can cause very high flushing rates of water through the lakes. The observed values are however regarded as non-limiting, being well above the thresholds of $0.03-0.06 \mathrm{mg} \mathrm{Si} \mathrm{L}^{-1}$ (Willén 1991). Available data on chlorophyll a concentration of these lakes (ISMA 1998) average 10.68 $\mu \mathrm{g} \mathrm{L}^{-1}$ and support their placement in oligo- to mesotrophic water bodies.

As can be seen by synoptically comparing the time of occurrence of diatom peaks and the species mostly responsible of the proliferation (Fig. 2), the two lakes, in spite of similar thermal profiles, do not mirror each other dynamics. The relative blooms of some taxa are not simultaneous in the two lakes, testifying a relative independency of algal behaviour across the two waterbodies sharing climate and chemical inputs from the catchment basin.

In terms of functional grouping (Reynolds et al. 2002) the prevailing presences are those of euplanktonic diatoms of meso- to eutrophic epilimnia, sensitive to stratification and tolerant of nutrient deficiency. The massive presence in these high mountain lakes of Cyclotella spp., While Aulacoseira spp. results scarce, 


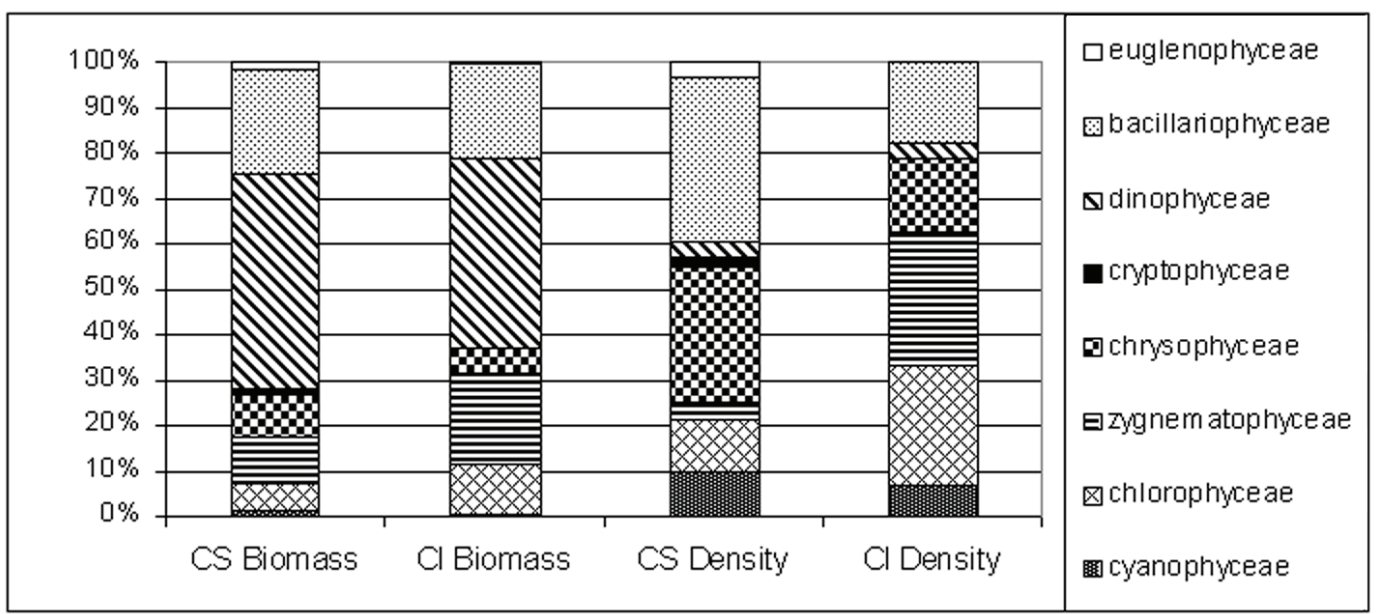

Fig. 4. Quantitative proportions of the different phytoplankton taxonomical groups in the two lakes. The average values of the tenyear period are shown.

indicates well buffered/non-acidified waters, an environment not overly nutrient-deficient. These conditions are typical of the Avisio basin lakes, and agree with the water chemical values recorded (Tolotti 2006). The occurrence of Fragilaria crotonensis, F. capucina and F. ulna is in line with a scenario of nutrient rich lakes (Willén 2000); the first taxon is reported as indicator of eutrophic conditions (Rosén 1981). The co-dominance of $T$. flocculosa and F. crotonensis is an interesting situation as they have opposite requirements for silica, but share a relatively low demand of phosphorus and a marked resistance to grazing (Willén 1991). In addition, Cyclotella spp., typical of oligotrophic lakes, is tolerant to nutrient deficiency and can grow in winter conditions (Reynolds 2002), which is consistent with their prompt appearance in spring that we frequently observed in our lakes. While $F$. crotonensis dominates in both lakes (Tab. 2) Cyclotella spp. ranks second but only in LCS while in LCI it appears represented by $C$. comensis. F. capucina is six times more abundant in $\mathrm{LCI}$ and other diatom taxa present at lower frequencies also show preferential representation in the lower lake. These include Pinnularia sudetica, Stauroneis anceps, Diatoma mesodon, and Cymbella silesiaca.

As concerns associations of diatom abundances with physico-chemical variables, we recorded a significant correlation with water temperatures. In rivers diatom blooms have been reported to be positively correlated with high water temperatures and low flows (Mitrovic et al. 2008). In high mountain lakes this link had not yet been adequately covered. The present study shows the role of water temperature as important environmental factor that appears tightly coupled with interesting correlations with intra- and inter-annual diatoms dynamics.

A very pronounced negative correlation ( $p$ $<0.0001)$ with water transparency resulted in LCS for both density and biomass, while in the smaller LCI the effect was below significance. This difference under- lines the usefulness of having available for sampling two lakes lying a few meters apart from each other but differing in size and depth. The negative relationship with transparency is expected for diatoms as light is known to be detrimental to their photosystem (Harris 1986). On the other hand the above phenomenon concerns the first $50 \mathrm{~cm}$, but, considering the whole water column, in these systems the reduced transparency is not only to be envisaged as a possible cause but also as a direct effect of algal growth, which explains its negative relationship with their densities. The extent of the euphotic zone $Z_{\mathrm{eu}}$ with respect to the water-mixing zone $\left(Z_{m}\right)$ is known to affect algal dynamics in lakes, Diatoms (heavier than other algal groups and better adapted to low radiation) are thereby reported to be advantaged over other more buoyant species in a context of more intense water mixing (Hutchinson 1967; Harris 1986; Reynolds 1984). Parallel analyses, with the same methods and sampling dates, on all the other phytoplankton divisions are in progress to verify the complementary dynamics of these (Trevisan et al., in preparation), an account of this analysis is shown in figure 4 showing the relative proportions of biomass and density for the different phytoplankton groups in the two lakes. The Relative Water Column Stability (RWCS), reporting how stable is the stratification of the temperatures in the water, is a parameter which has been applied in different instances on various lakes (Naselli-Flores \& Barone 2005; Becker 2009) Our measurements displayed average values of 50.34 for LCS and 36.55 for LCI The lower value observed for the smaller lake indicates conditions more prone to mixing of the waters, which are more favourable to diatoms and could provide a relief from the negative effect of light intensity by continuously removing cells from the upper water zone. The data are in line with the fact that only in LCS their negative correlation with water transparency is observed at significant level. The reasons for which LCI features more mixed conditions 
(lower RWCS) is supposedly its shallower nature (average depth $3.8 \mathrm{~m}$ ) as a consequence of which the wind-driven mixing involves a more substantial volume of this lake, compared to LCS whose average depth is $5.4 \mathrm{~m}$.

In terms of response to physico-chemical parameters another difference arises between the two lakes concerning the effect of water level. In the smaller water body LCI a significant negative correlation appears between this variable and diatom density while no effect is evident in LCS. Given the shallower depth of LCI and the sensitivity of diatoms to light, the negative effect of lower water levels in this lake is in line with the predictions. The layer of water not reached by radiation would be thinner in emptier basins of smaller depth thus reducing the sheltering space for light-sensitive organisms. As for $\mathrm{pH}$ and previous week rainfall we observed somewhat stronger correlations for LCI compared to LCS. These data concur to strengthen the view of a tighter chemical control/response in the smaller lake. Having a volume of one third compared to the larger lake, despite their equal exposure to inputs from the catchment basin, appears to play a significant role in the dynamics of the phytoplankton. One of the remarkable results in terms of difference between the two lakes is the mean annual biovolume of the diatoms (estimated by multiplying for the unit volume of each taxon) which was considerably higher in the lower lake. This difference seems also to be relative to species variations in the two communities as the densities were not as different $\left(233.7\right.$ cells $\mathrm{mL}^{-1}$ in LCS vs 273.5 cells $\mathrm{mL}^{-1}$ in LCI). The environment of the smaller lake, with its chemical parameters and their different correlations as discussed above, appears to select different phytoplankton members and to enhance their relative numbers. Dissolved nutrient comparisons indicate that the main difference appearing between the lakes is limited to the active phosphorus content which is nearly double in the lower lake (mean $5 v s 2 \mu \mathrm{g} \mathrm{L}^{-1}$ ) whose maxima showed even larger differences (18 vs 5 $\left.\mu \mathrm{g} \mathrm{L}^{-1}\right)$. However in some dates values were close to the detection limit. Total $\mathrm{P}$ and $\mathrm{N}$ are instead rather comparable. The advantage for diatoms in LCI is in part likely due to the lower RWCS value which is a better condition for this algal group which relies on water mixing.

However the most rationale basis to explain the different productivity of the two lakes is presumably their different depth. In the more productive shallower LCI the euphotic zone represents a more substantial proportion of the whole volume, while in LCS, even when the photosynthetically-proficient layers could reach equal levels of productivity, the deeper aphotic zone would dilute out the phytoplankton yield leading to lower values of density end biomass per unit volume.

All considered, the two lakes of Colbricon, appear to constitute a peculiar set of coupled model environ- ments, offering the rare opportunity to study variations imposed by given environmental constraints while keeping other variables constant. The availability of a ten-years consecutive dataset is a further element of strength of the comparison. Studies are in progress to expand the analyses to data regarding all the remaining phytoplankton divisions as well as the bacterial components, in order to trace a general picture of size-dependent responses in high mountain lake biology.

\section{ACKNOWLEDGEMENTS}

Giuseppe Morabito is gratefully acknowledged for critical reading of the manuscript and providing useful suggestions.

\section{REFERENCES}

Ampel, L., B. Wohlfarth, J. Risberg \& D. Veres. 2008. Paleolimnological response to millennial and centennial scale climate variability during MIS 3 and 2 as suggested by the diatom record in Les Echets, France. Quat. Sci. Rev., 27: 1493-1504.

ARPAV. 2007. Studio della qualità delle acque dei piccoli laghi alpini. Progetto INTERREG III. Cierre Grafica, Verona: $392 \mathrm{pp}$.

Barbanti, L., R. de Bernardi, G. Giussani \& P. Giulizzoni. 1993. Laghi. In: Marchetti R. (Ed.), Ecologia applicata, Parte I. Città Studi, Milano: 70-87.

Becker, V., V.L. M. Huszar \& L.O. Crossetti. 2009. Responses of phytoplankton functional groups to the mixing regime in a deep subtropical reservoir. Hydrobiologia, 628: 137-151.

Boggero, A., A. Marchetto, A. Barbieri, A. Sassi, M. Conedera, G.A. Tartari \& R. Mosello. 1996. Idrochimica dei laghi alpini del Canton Ticino (Alpi Centrali) in relazione con la chimica delle precipitazioni. Documenta Ist. ital. Idrobiol., 57: 1-57.

Cabrera, S., M. Lopez \& B. Tartarotti. 1997. Phytoplankton and zooplankton response to ultraviolet radiation in a high-altitude Andean lake: short- versus long term effects. J. Plankton Res., 19: 1565-1582.

Catalan, J., C.J. Curtis \& M. Kernan. 2009. Remote European mountain lake ecosystems: regionalisation and ecological status. Freshwat. Biol., 54: 2419-2432.

Chepurnov, V.A., D.G. Mann, K. Sabbe \& W. Vyverman. 2004. Experimental studies on sexual reproduction in diatoms. Int. Rev. Cytol., 237: 91-154.

Chiaudani, G. \& M. Vighi. 1974. The N/P ratio and tests with Selenastrum to predict eutrophication in lakes. Water Res., 8: 1063-1069.

Curtis, C.J., S. Juggins, G. Clarke, R.W. Battarbee, M. Kernan, J. Catalan, R. Thompson \& M. Posch. 2009. Regional influence of acid deposition and climate change in European mountain lakes assessed using diatom transfer functions. Freshwat. Biol., 54: 2555-2572.

Ferris, J.A., \& J.T. Lehman. 2007. Inter-annual variation in diatom bloom dynamics: Roles of hydrology, nutrient limitation, sinking, and whole lake manipulation. Water Res., 41: 2551-2562.

Festi, F. \& F. Prosser. 2000. La flora del Parco Naturale di Paneveggio-Pale di S. Martino. Annali Museo Civico Rovereto, Suppl. 13 (1997): 438 pp.

Fott, J., M. Blazo, E. Stuchlik \& O. Strunecky. 1999. Phytoplankton in three Tatra Mountain lakes of different acidification status. J. Limnol., 58: 107-116.

Hakanson, L. 1980. An ecological risk index for aquatic pollution control. A sedimentological approach. Water Res., 14: $975-1001$. 
Halac, S., M. Felipe, L. Camarero, S. Sommaruga-Wögrath, R. Psenner, R. Catalan \& R. Sommaruga. 1997. An in situ enclosure experiment to test the solar UV-B impact on plankton in a high altitude lake. Lack of effect on phytoplankton composition and growth. J. Plankton Res., 19: $1671-1687$.

Harris, G.P. 1986. Phytoplankton Ecology: structure, function and fluctuation. Chapman and Hall, London: 384 pp.

Hinder, B., M. Gabathuler, B. Steiner, K. Hanselmann \& H.R. Preisig. 1999. Seasonal dynamics and Phytoplankton diversity in high mountain lakes (Jöri Lakes, Swiss Alps). J. Limnol., 58: 152-161.

Hutchinson, G.E. 1967. A treatise on limnology, 2. J. Wiley $\&$ Sons, New York: $1115 \mathrm{pp}$.

IASMA, 1998. Caratteristiche limnologiche dei laghi del Trentino. Rapporto 1997. Istituto Agrario di S. Michele a/Adige: $144 \mathrm{pp}$.

Kernan M., M. Ventura, P. Bitusík, A. Brancelj, G. Clarke, G. Velle, G.G. Raddum, E.V. Stuchlík, \& J. Catalan. 2009. Regionalisation of remote European mountain lake ecosystems according to their biota: environmental versus geographical patterns. Freshwat. Biol., 54: 2470-2493.

Koinig, K.A., R. Schmidt, S. Sommaruga-Wögrath, R. Tessadri \& R. Psenner. 1998. Climate change as the primary cause for $\mathrm{pH}$ shifts in a high alpine lake. Water Soil Air Pollut., 104: 167-180.

Krammer, K. \& K. Lange-Bertalot. 1986-1991-1998 - Bacillariophyceae. In: A. Pascher (Ed.), Süßwasserflora von Mitteleuropa. 1. Naviculaceae: 876 pp.; 2. Bacillariaceae, Epithemiaceae, Surirellaceae: 596 pp.; 3. Centrales, Fragilariaceae, Eunotiaceae: 576 pp.; 4. Achnanthaceae, Ergenzungen zu Navicula (Lineolate) und Gomphonema: 436 pp. Gustav Fischer Verlag, Stuttgart.

Lami, A. \& A. Boggero (Eds). 2006. Ecology of high altitude aquatic systems in the Alps. Hydrobiologia, 562 (1): 246 pp.

Mann, D.G. 1999. The species concept in diatoms. Phycologia, 38: 437-495.

Mitrovic, S.M., B.C. Chessman, A. Davie, E.L. Avery \& N. Ryan. 2008. Development of blooms of Cyclotella meneghiniana and Nitzschia spp. (Bacillariophyceae) in a shallow river and estimation of effective suppression flows. Hydrobiologia, 596: 173-185.

Mosello, R., A. Marchetto, M.C. Brizzio, M. Rogora \& G.A. Tartari. 2000. Results from the Italian participation in the International Co-operative Programme on Assessment and Monitoring of Acidification of Rives and Lakes (ICP Waters). J. Limnol., 59: 47-54.

Naselli-Flores, L. \& R. Barone. 2005. Water-level fluctuations in Mediterranean reservoirs: setting a dewatering threshold as a management tool to improve water quality. Hydrobiologia, 548: 85-99.

Nauwerck, A. 1966. Beobachtungen ilber das Phytoplankton klarer Hochgebirgsseen. Schweiz. Z. Hydrobiol., 28: 4-28.

Nauwerck, A. 1994. A survey on water chemistry and plankton in high mountain lakes in northern Swedish Lapland. Hydrobiologia, 274: 91-100.

O.E.C.D. 1982. Eutrophication of water: monitoring, assessment and control. O.E.C.D., Paris: 150 pp.

Padisak J., F. Barbosa, R. Koschel \& L. Krienitz. 2003. Deep layer cyanoprokaryota maxima are constitutional features of lakes: examples from temperate and tropical regions. Arch. Hydrobiol., Special Issues, Adv. Limnol., 58: 175-199.

Payette, S. 2008. Diatoms: faithful proxy indicators of climate change? Front. Ecol. Environ., 6: 411-411.

Pechlaner, R. 1971. Factors that control the production rate and biomass of phytoplankton in high mountain lakes. Mitt. int. Ver. Limnol., 19: 125-145.
Pfister, P. 1988. III Phytoplankton in Tiroler Hochgebirgsseen. In: R. Psenner (Ed.), Versauerung von Hochgebirgsseen in kristallinen Einzusgebieten Tirols und Kärnterns. Bundesministerium für Land - und Fortwirtschaft, Wien: $335 \mathrm{pp}$.

Prygiel, J. \& M. Coste. 1998. Mise au point de l'Indice Biologique Diatomée, un indice diatomique pratique applicable au réseau hydrographique français. Eau Ind. Nuis., 211: 40-45.

Reynolds, C.S. 1984. The ecology of freshwater phytoplankton. Cambridge. Univ. Press, Cam- bridge and New York: $384 \mathrm{pp}$.

Reynolds, C.S., V.L. Huszar, C. Kruk, L. Naselli-Flores \& S. Melo. 2002. Toward a functional classification of the freshwater phytoplankton. J. Plankton Res., 24: 417-428.

Round, F.E., R.M. Crawford, \& D.G. Mann. 1990. Diatoms: biology and morphology of the genera. Cambridge Univ. Press, Cambridge: $747 \mathrm{pp}$.

Rosén, G. 1981. Phytoplankton indicators and their relations to certain chemical and physical factors. Limnologica, 13: 263-290.

Rott, E. 1988. Some aspects of the seasonal distribution of flagellates in mountain lakes. Hydrobiologia, 161: 159-170.

Salmaso, N. \& F. Decet. 1997. Seasonal and interannual changes of chemical characteristics and phytoplankton in a mountain lake of the eastern Italian Alps (Lake Calaita, Trentino). Int. Rev. Ges. Hydrobiol., 82: 15-31.

Schmidt, R., C. Kamenik, H. Lange-Bertalot \& R. Klee. 2004. Fragilaria and Staurosira (Bacillariophyceae) from sediment surfaces of 40 lakes in the Austrian Alps in relation to environmental variables and their potential for paleoclimatology. J. Limnol., 63: 171-189.

Tartari, G.A. \& R. Mosello. 1997. Metodologie analitiche e controlli di qualità nel laboratorio chimico dell'Istituto Italiano di Idrobiologia. Documenta Ist. ital. Idrobiol., 60: $160 \mathrm{pp}$

Tilzer, M.M.. 1972. Dynamik und Produktivitat von Phytoplankton und pelagischen. Bakterien in einem Hochgebirgssee. Arch. Hydrobiol., Suppl. 40: 210-273.

Tolotti, M. 2001. Phytoplankton and littoral epilithic diatoms in high mountain lakes of the Adamello-Brenta Regional Park (Trentino, Italy) and their relation to trophic status and acidification risk. J. Limnol., 60: 171-188.

Tolotti, M. 2006. Fitoplancton. In: Cantonati, M. \& M. Lazzara (a cura di), I laghi di alta montagna del bacino del Fiume Avisio (Trentino orientale). Monografie del Museo Tridentino di Scienze Naturali, 3. Museo Tridentino di Scienze Naturali, Trento: 99-128.

Trevisan, R. \& A. Rosso. 1999. I laghi di Colbricon (Trentino Orientale): principali caratteristiche morfometriche e limnologiche. Studi Trent. Sci. Nat., Acta Biol., 76: 87-104.

Utermohl, H. 1958. Zur Vervolkommnung der quantitaiven Phytoplankton Methodik. Verh. int. Ver. Limnol., 9: 1-38.

Vanormelingen, P, E. Verleyen \& W. Vyverman. 2008. The diversity and distribution of diatoms: from cosmopolitanism to narrow endemism. Biodivers. Conserv. 17: 393-405

Willén, E. 1991. Planktonic diatoms - an ecological review. Algological Studies, 62: 69-106.

Willén, E. 2000. Phytoplankton in water quality assessment an indicator concept. In: P. Heinonen, G. Ziglio \& A. Van der Becken (Eds), Hydrological and Limnological Aspects of lake monitoring. Wiley, New York: 58-80.

Received: November 2009

Accepted: April 2010 